\title{
Description of the Ootheca of Turbinella laevigata (Mollusca, Gastropoda)
}

\author{
Helena Matthews-Cascon ${ }^{1 *}$, Cristina de Almeida Rocha-Barreira ${ }^{1}$; Carlos Meirelles ${ }^{1}$; \\ Gregorio Bigatti $^{2}$ and Pablo Penchaszadeh ${ }^{2}$ \\ ${ }^{I}$ Departamento de Biologia; Instituto de Ciências do Mar; Universidade Federal do Ceará; 60455-760; Fortaleza - \\ CE - Brasil. ${ }^{2}$ Laboratorio Invertebrados I; Museo Argentino de Ciencias Naturales "Bernardino Rivadavia"; \\ Facultad de Ciencias Exactas y Naturales; Universidad de Buenos Aires; Buenos Aires - Argentina
}

\begin{abstract}
Turbinella laevigata is found since the intertidal zone up to $40 \mathrm{~m}$ depth, being endemic of Brazil where it occurs from the state of Amapá to the state of Espirito Santo. The objective of this study was to describe the ootheca of this species. Fifteen samples collected in the Olho d'Água Beach, City of Icapui and Fleixeiras Beach, City of Trairí, both in Ceará State, Northeast Brazil, were studied. The spawns were composed by $15+1-1.4$ SD capsules and had $63+$ +/ 6.4 SD mm of length with 41 +/- 2.5 SD mm of width. They had a convex and a concave surface, and plaited edges that drew out until the basal membrane, to which they joined forming a medial ridge. This species apparently produced a high amount of nurse eggs. The early juveniles measured 6.4 +/- 0.7 SD mm of length and they presented a protoconch with three whorls.
\end{abstract}

Key words: Reproduction, Mollusca, Turbinellidae

\section{INTRODUCTION}

The Turbinellidae are represented in Brazil by five species: Vasum cassiforme (Kiener, 1841), Turbinella laevigata Anton, 1839, Fugurofusus sarissophorus (Watson, 1882), Fugurofusus. ecpheroides Harasewych, 1983, Fugurofusus coronatus (Penna-Neme and Leme, 1978) (Rios, 1994). Turbinella laevigata Anton, 1839 is endemic of Brazil occurring from the state of Amapá to the state of Espirito Santo (Rios,
1994). It inhabits burrows in sand or mud next to beach rocks (Fig. 1) and is found since the intertidal zone up to 40 meter depth.

Turbinella laevigata has a large shell measuring up to $180 \mathrm{~mm}$ of length. The teleoconch has eight whorls of marked sutures and the protoconch is mamiliform, with three smooth whorls with deep sutures and the separation to the teleoconch well defined (Matthews-Cascon, 1985). The color of the shell is dull white, but is often hidden by a thick, brown periostracum.

\footnotetext{
* Author for correspondence: hmc@ufc.br
} 


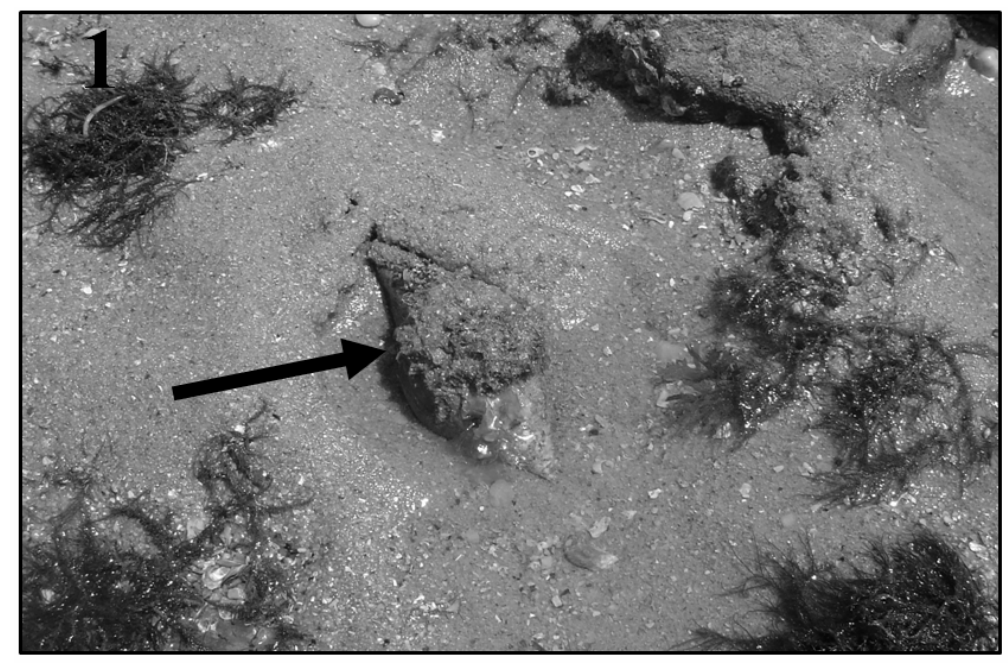

Figure 1 - Adult individual in the intertidal zone. Shell size $=15 \mathrm{~cm}$.

Turbinellidae species are gonochoristic and present internal fertilization. The prosobranch gastropods present different strategies in the reproduction process, and for species of benthic marine gastropods, the reproductive strategy, as well as its larval life, are essential factors for their adaptation to the environment, as well as for the extension of its geographic distribution (Thorson, 1950).

The process of encapsulating eggs after the fertilization is a common phenomenon, with the most elaborated and varied examples occurring in the prosobranch gastropods. Its adaptative advantages are related to protection and accumulation of larval nutricional resources (Purchon, 1968). The larvae of species that deposit eggs in capsules generally do not suffer as great predatory pressure as those that spend part or all the development without any type of protection (D'Asaro, 1986).

The egg capsules of prosobranch gastropods work in the protection against predators, bacteria and stresses of the physical environment, being structurally and chemically complex and having a high energetic cost (Penchaszadeh and Miloslavich, 2001). They are frequently, proteinaceous envelops (Goldsmith et al., 1978), deposited in specific types of substratum that supply camouflage, or that assure nutritional resources for the juveniles when they just come out (Andrews, 1935; Bandel, 1974; Fowler, 1980). The encapsulation usually offers a larger space for the development than the lumen of the oviduct, allowing that proportionally more eggs can be developed in youthful before being set free (D'Asaro, 1986). Moreover, it allows the larvae to have access to extraembryonic or secondary supplements of food proceeding from the accessory glands (intracapsular or perivitelline liquid), nutritional eggs and even through the substances that form the walls of the capsule (Pechenik, 1986; Rawlings, 1994; Miloslavich, 1996). In this work, the egg capsules of Turbinella laevigata are described.

\section{MATERIALS AND METHODS}

The Turbinella laevigata oothecae studied in the present work were collected from March to May 2004. Fifteen oothecae were examided, collected in the Olho d'Água Beach, City of Icapuí (4 $39^{\prime}$ 'S, $\left.37^{\circ} 27^{\prime} \mathrm{W}\right)$, and Fleixeiras Beach, City of Trairí ( $3^{\circ}$ $\left.22^{\prime} \mathrm{S}, 39^{\circ} 25^{\prime} \mathrm{W}\right)$, both in the state of Ceará, Northeast Brazil (Fig. 2). The studied material has been deposited at the "Henry Ramos Matthews Malacological Collection" of the Universidade Federal do Ceará (UFC). 


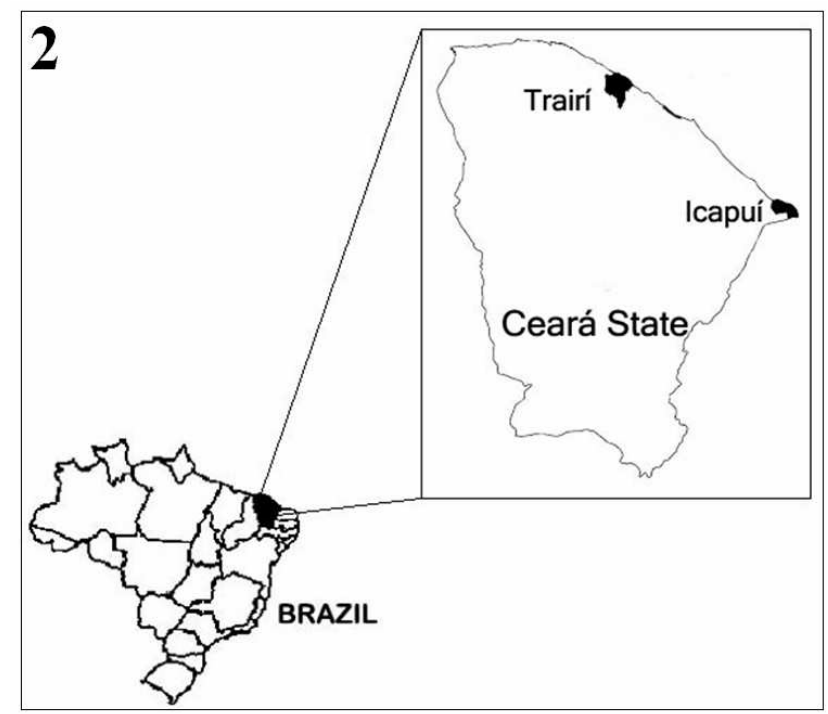

Figure 2 - Studies sites at Ceará State, Northeast Brazil.

The total length and maximum width of each ootheca were measured as well as the diameter of the capsule, represented by the distance between the lateral edges, and the thickness of the capsule, represented by the distance between the upper marginal ridge and the medial ridge. The measures were carried through with a caliper of $0.1 \mathrm{~mm}$ of precision. The egg capsules and the juveniles were photographed with a digital camera linked to a stereoscopic microscope.

\section{RESULTS}

The $T$. laevigata oothecae presented a complex and massive structure (Fig. 3A and 3B), and had on average $63+/-6.4$ SD mm of length (50.8 - 74 $\mathrm{mm}, \mathrm{N}=15)$ and $41+/-2.5 \mathrm{SD}$ mm of width (38 $45 \mathrm{~mm}, \mathrm{~N}=15)$. Each T. laevigata oothecae was composed on average by $15+/-1.4$ SD (13 - 18, $\mathrm{N}=15$ ) opaque discoid capsules, with each capsule measuring on average $32.3+/-6.4 \mathrm{SD} \mathrm{mm}$ of diameter $(15.6-40.3 \mathrm{~mm}, \mathrm{~N}=15)$ and $0.4+/-0.09$ $\mathrm{SD} \mathrm{mm}$ of thickness $(0.22-0.57 \mathrm{~mm}, \mathrm{~N}=15)$ (Fig. 3C).
The capsules presented in each oothecae were attached to a common basal membrane which was fused into a rigid stalk. The spawns were fixed in red seaweed (Bryothamnion seaforthii) by one of the extremities (Fig. 3D).

Each capsule had a convex and a concave surface and plaited edges that drew out until the basa? membrane, to which they joined forming a medis.n. ridge. In some capsules, a disruption in the central area was found, where the capsules had fewer eggs. This disruption was probably the escape aperture.

The capsules located in the two extremities of the spawning were smaller than the others, and the one near the stalk was empty in all oothecae examined. The egg number in each capsule was on average 240 in the only ootheca were it was counted. This species had an intracapsular metamorphosis and the juveniles found inside the capsules in more advanced stage of development presented on average, $6.4+/-0.7 \mathrm{SD} \mathrm{mm}$ of length $(5-8.2 \mathrm{~mm}$, $\mathrm{N}=50$ ) and three complete whorls of protoconch. It was possible that it was around this size that the juveniles left the egg capsules (Fig. 4A and 4B). 

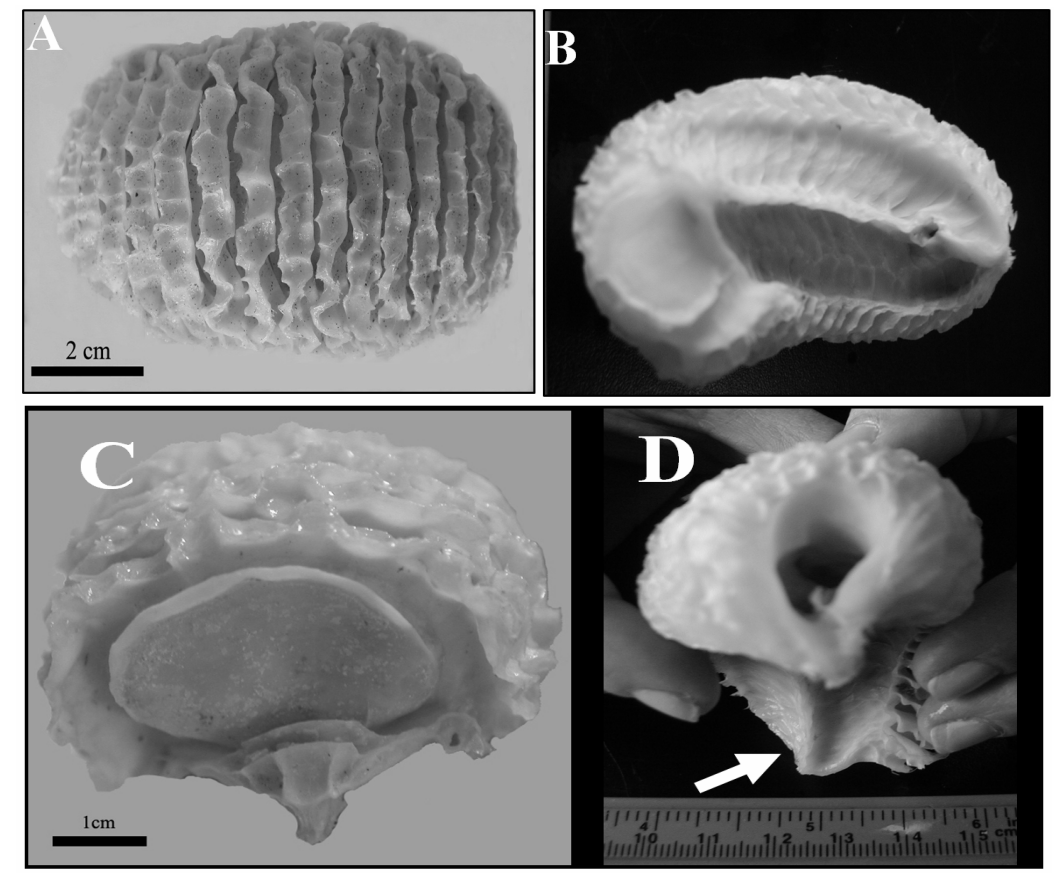

Figure 3 - Egg mass of Turbinella laevigata. A. Egg capsules - apical view. B. Egg capsules basal view. C. Capsule of the spawning. D. Egg capsules showing the extremity modified to hold itself to the substratum.

Most of the egg capsules presented animals in different stages of development. I'יst one ootheca had the animals in more advanced stage in almost all capsules. In this spawn, newborns were counted, with 10 individuals in each capsule and a total of 150 for the whole ootheca (Fig. 4C).
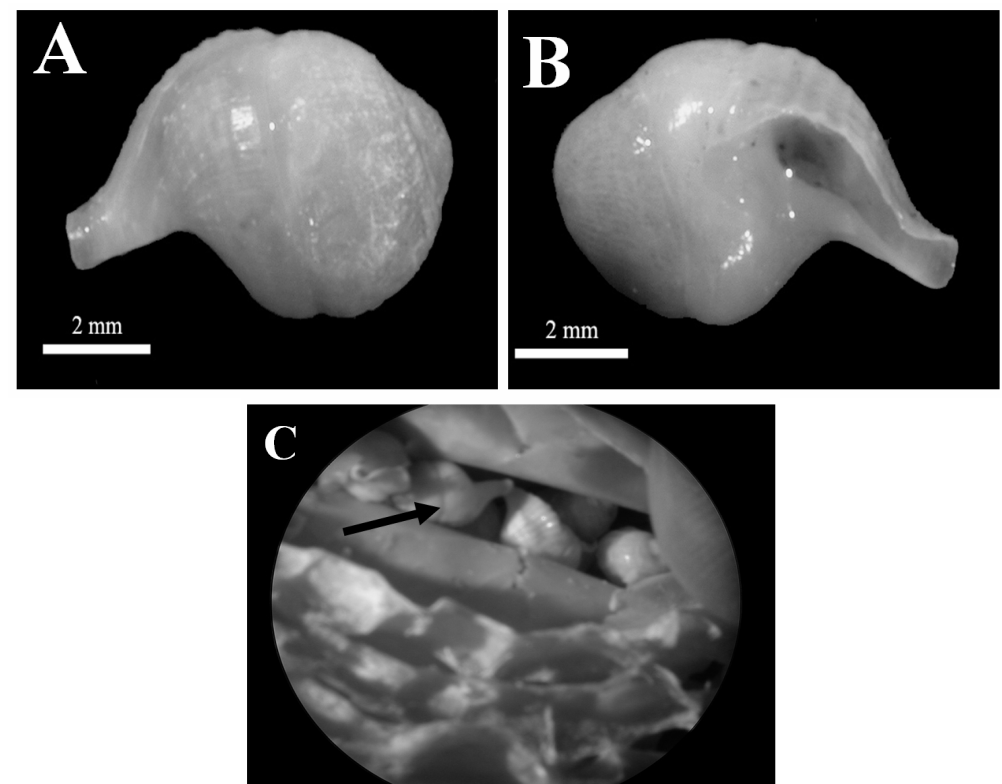

Figure 4 - Juvenile of Turbinella laevigata. A. Dorsal view. B. Ventral view. C. Juveniles inside the capsule. 


\section{DISCUSSION}

According to Matthews-Cascon (1985), the spawning of Turbinella laevigata occurs during the whole year, but has a higher incidence during the months of November and December.

In each $T$. laevigata capsule, the average number of eggs (240) was much higher than the average number of juveniles (10), which indicated that most of the eggs were nutritional. D'Asaro (1970) also observed nurse eggs in the Turbinellidae Vasum muricatum but not in Xancus angulatus, indicating that nutritional eggs were not present in all members of this family and that this feature could be helpful in the analysis of the phylogenetic relationships among the Turbinellidae taxa.

All T. laevigata oothecae studied were attached to red algae, whereas the $X$. angulatus egg mass was found attached to a piece of organic debris (D'Asaro, 1970).

The average number of egg capsules presented in each $T$. laevigata oothecae (15) was quite different from that observed for other Turbinellidae species: three capsules for $V$. muricatum, and ten capsules for X. angulatus (D'Asaro, 1970). The absence of eggs in the basal capsule, observed in the present study for T. laevigata oothecae, was also observed for X. angulatus by D'Asaro, 1970

The average number of ten juveniles for each $T$. laevigata capsule, observed in the present study, was higher than the one observed by D'Asaro (1970) for X. angulatus (2 to 5 juveniles for each capsule, with a total of 33 for the egg mass) but it was fewer than the one observed by the same author for one capsule of $V$. muricatum (165 embryos). All these three species have direct development, which can be a constant feature for the Turbinellidae species.

\section{ACKNOWLEDGEMENTS}

We are very grateful to Dr. Paulo Cascon who provided useful insights and for revising the English language. We would like to thank CAPES and SECYT for their financial support.

\section{RESUMO}

Turbinella laevigata é encontrada desde a zona entre marés até $40 \mathrm{~m}$ de profundidade, sendo endêmica do Brasil onde ocorre desde o Estado do Amapá até o Espírito Santo. O objetivo deste estudo foi descrever a ooteca de Turbinella laevigata. Quinze amostras foram coletadas na Praia de Olho d’Água, Município de Icapuí e na Praia de Flexeiras, Município do Trairí, ambos no Estado do Ceará, Nordeste do Brasil, foram estudadas. As desovas de T. laevigata foram compostas por $15+/-1.4 \mathrm{SD}$ cápsulas e mediram $63+/-6.4$ SD mm de comprimento e 41 +/- $2.5 \mathrm{SD}$ $\mathrm{mm}$ de largura. Todas as cápsulas estavam fixadas pela membrana basal, a qual tinha a extremidade modificada para se prender ao substrato. Elas possuem uma superfície concava e outra convexa, apresentando margens pregueadas, que se prolongavam até a membrana basal, à qual se uniam formando uma prega. Esta espécie aparentemente produz uma grande quantidade de ovos nutritivos. A concha dos juvenis mediu 6.4 +/- 0.7 SD mm de comprimento e apresentou uma protoconcha com 3 voltas.

\section{REFERENCES}

Andrews, E. A. (1935), The egg capsules of certain Neritidae. J. Morphol., 57 (1), 31-59.

Bandel, K. (1974), Studies on Littorinidae from the Atlantic. Veliger, 17 (2), 92-114.

D’Asaro, C. N. (1970), Egg capsules of prosobranch mollusks from south Florida and the Bahamas and notes on spawning in the laboratory. Bull. Mar. Sci., 20 (2), 414-440.

D’Asaro, C. N. (1986), Laboratory spawning, egg membranes and egg capsules of 14 small marine prosobranchs from Florida and Bimini, Bahamas. Am. Malacol. Bull., 4 (2), 185-199.

Fowler, B. H. (1980), Reproductive biology of Assiminea californica (Tryon, 1865) (Mesogastropoda: Rissoacea). Veliger, 23 (2), 163166.

Goldsmith, L. A.; Hanigan, H. M.; Thorpe, J. M. and Lindberg, K. H. (1978), Nidamental gland precursors of the egg capsule protein of the gastropod mollusk Busycon carica. Comp. Biochem. Phys., 59, 133-138.

Matthews-Cascon, H. (1985), A família Turbinellidae no Brasil (Mollusca: Gastropoda). Arq. Ciên. Mar, 24, 1-44.

Miloslavich, P. (1996), Nurse-egg feeding prosobranchs: a comparative biochemical and electrophoretic analysis of eggs and hatchlings. Am. Malacol. Bull., 13, 37-46.

Pechenik, J. A. (1986), The encapsulation of eggs and embryos by mollusks: an overview. Am. Malacol. Bull., 4, 165-172. 
Penchaszadeh, P. E. and Miloslavich, P. (2001), Embryonic stages and feeding substances of South American volutid Voluta musica (Caenogastropoda) during intracapsular development. Am. Malacol. Bull., 16, 21-31.

Purchon, R. D. (1968), The Biology of the Mollusca. Pergamon Press, Oxford.

Rawlings, T. A. (1994), Encapsulations of eggs by marine gastropods: effect of variation in capsule from on the vulnerability of embryos to predation. Evolution, 48 (4), 1301-1313.
Rios, E. C. (1994), Seashells of Brazil. Editora da Fundação Universidade do Rio Grande; Rio Grande, Brazil.

Thorson, G. (1950), Reproductive and larval ecology of marine bottom invertebrates. B iol. Rev., 25 (1), 1-45.

Received: November 06, 2006; Revised: July 09, 2007; Accepted: June 16, 2008. 